\title{
Chapter 19 \\ Compact City Corresponding to the Advanced Transport Systems
}

\author{
Akinori Morimoto
}

\begin{abstract}
Location normalization plans that are currently being established across the country encourage a loose approach to land utilization guidance by establishing the areas where urban function guidance and residential guidance apply. We will consider some hints as to how to proceed with urban downsizing by looking back at how urban areas expanded during the period of population growth. It is important that the characteristics and roles of each transport system are reorganized and that they are skillfully incorporated into cities. In particular, the formation of transfer points between main line transport systems and branch line transport systems is a key to the formation of compact cities.
\end{abstract}

Keywords Compact city $\cdot$ Advanced transport systems $\cdot$ Land use and transport

\subsection{Introduction}

Currently, Japan is experiencing significant depopulation. According to 2017 estimates from the National Institute of Population and Social Security Research, the population in 2050 will be 101.92 million, which is equivalent to that of 1970 , while the population in 2100 will reduce to 59.72 million people, which is equivalent to that of 1925 (see Fig. 19.1).

The transition of a continuously depopulating and aging society increases the substantive and relative burden on people of working age, and local governments will inevitably undergo difficulties in financial management due to reduced tax yields and increased expenditure.

One of the reasons for the implementation of the compact city policy in Japan is the transition to a sustainable urban structure to address the reduced population. Housing estates built by clearing away forests and agricultural land and urban areas

\footnotetext{
A. Morimoto $(\bowtie)$

Waseda University, Tokyo, Japan

e-mail: akinori@waseda.jp

Y. Asami et al. (eds.), Frontiers of Real Estate Science in Japan, New Frontiers in 


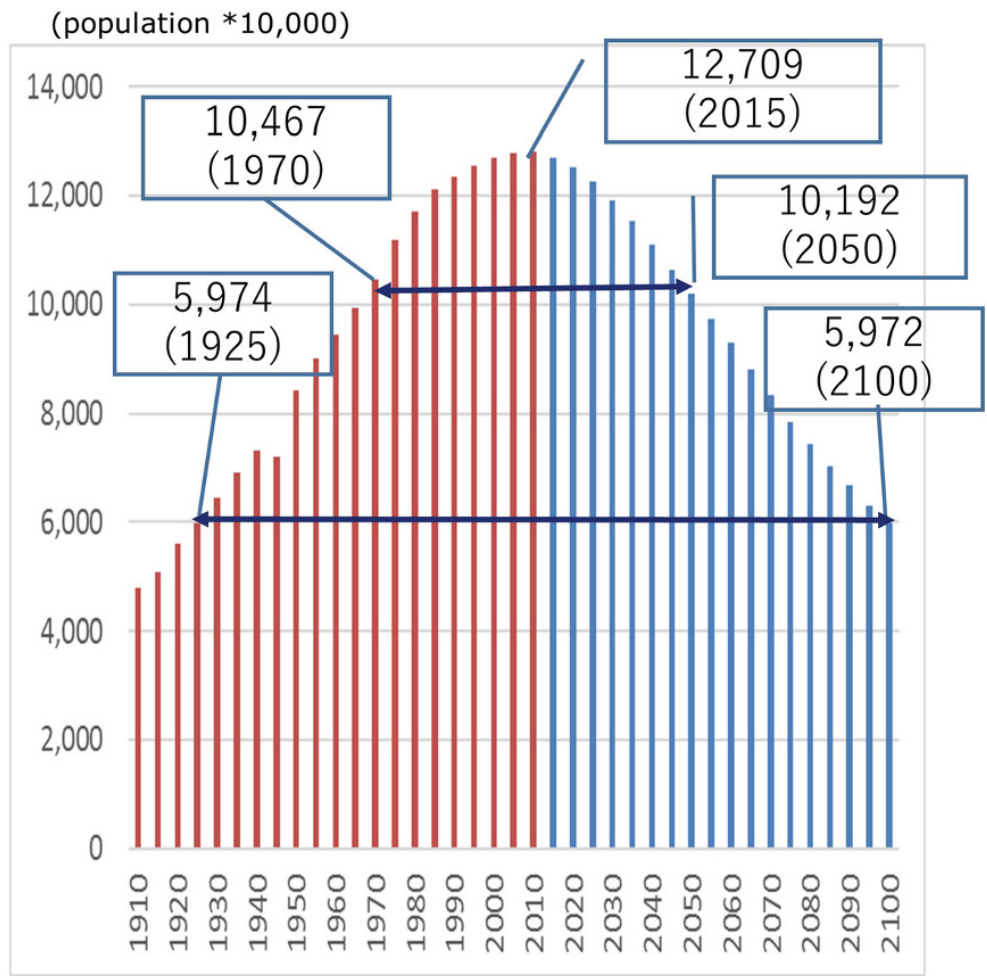

Fig. 19.1 Japanese population transition and estimates

that expanded through suburban sprawl during the period of population growth have become a major burden during this period of depopulation. While there are the same operation and management costs for infrastructure such as water and sewer services, bridges, and roads, the cost per person will continue to increase because the number of people bearing the financial responsibility for such infrastructure is decreasing. With increasing costs for medical care and welfare costs to support a rapidly aging society, securing the operation and maintenance expenses for urban areas is a problematic issue for all local governments. Downsizing cities in an intelligent manner to address the reduced population has become a matter of urgency for Japan.

In that case, how can cities that have expanded be made more compact? Location normalization plans that are currently being established across the country encourage a loose approach to land utilization guidance by establishing the areas where urban function guidance and residential guidance apply. While some results can be expected from this, it is not clear whether it will be enough. In this paper, we will consider some hints as to how to proceed with urban downsizing by looking back at how urban areas expanded during the period of population growth. 


\subsection{Relation Between Land Use and Transport}

Historically, the development of transportation facilities greatly contributed to the expansion of urban areas. At a time when people predominantly moved about on foot, urban areas were concentrated to an area of within about 30 min walk from the center. In the Meiji era, when railroads were constructed, the center of the city gradually moved to the areas around stations, and metropolises have formed by connecting several cities cooperatively through the development of railway network. In the 1960s, as automobile ownership rapidly increased, the outskirts of urban areas further expanded, and various facilities were relocated in the suburbs, including public facilities, such as municipal offices and hospitals.

Land use changes as transport changes, too, and both are often compared to "chicken-and-egg relation." In general, the demand for transport is derived demand of land use. If the primary demand for land use changes, demand for transport also changes accordingly. This relationship is shown in Fig. 19.2. Urban activities are performed and transportation activities are derived accordingly. Transportation facilities are improved in order to alleviate traffic jam, which is caused by increases in transportation activities. However, changing the supply of transportation facilities has an effect on the location of urban facilities.

Urban activities were increasing during periods of population increase, and transportation activities increased accordingly. As the supply did not keep up with rapidly increasing demand, various urban problems arose, such as housing shortages, traffic congestion, and environmental issues. The objective of city planning was the healthy development of cities and the promotion of public welfare, and it can be interpreted that the city planning concentrated on how best to balance supply with demand.

The process of keeping a balance between supply and demand is different in the fields of land use and transport. Land use is often formed primarily by the market economy. For example, a housing shortage due to an increasing population can be mitigated through the real estate market by the construction of private apartments, and balance can be restored in a relatively short time. On the other hand, when providing road transportation facilities in response to an increased demand for transport, time is often needed because it is planned by public agencies, and it is necessary to secure funds and gain the approval of residents. One example of this is the issue of urban roads authorized in city plan which have not yet moved into action

Fig. 19.2 Relation between land use and transportation

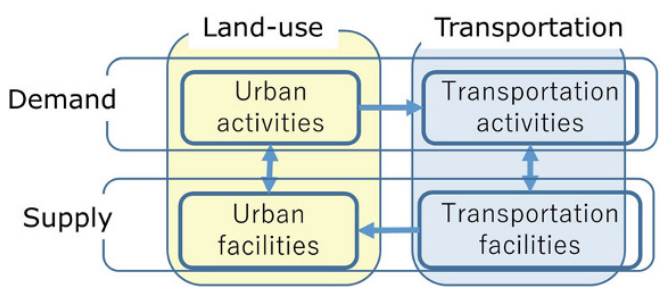


Table 19.1 Conflicting orientations of land use and transportation (Gakenheimer 1993)

\begin{tabular}{l|l|l}
\hline & Land use planning & Transportation planning \\
\hline 1. Scales of concern & Small & Network \\
\hline 2. Objectives of planning & Complex & Simple \\
\hline 3. Horizons of confident projection & Short & Longer \\
\hline 4. Techniques of analysis & Ad hoc & Standardized \\
\hline 5. Levels of government involved & Local & Regional and national \\
\hline 6. Prospects for implementation & Low & High \\
\hline 7. Units of implementation & Small & Large \\
\hline 8. Levels of budget & Small & Large \\
\hline
\end{tabular}

over a long period of time. Whereas it is possible to respond to land use in a relatively short time, the provision of transport facilities must be dealt with in the long term.

Although the mutual relationship between land use and transport should preferably be taken into consideration when making plans, it is not easy to do this because they each have characteristics which differ in various ways. As shown in Table 19.1, Gakenheimer (1993) analyzes difference between the two by summarizing factors which cause disassociation between land use and transportation planning.

\subsection{Land Use from the Viewpoint of Transport}

Transport demand always comes first during periods of population growth, which means there is a delay in the provision of transport facilities. In contrast to this, what happens during periods of depopulation? If there is a decrease in the population which is the source of the demand for transportation, this may resolve the unbalance in the supply of transportation facilities, and it may be necessary to curtail supply plans in some areas-this includes a review of long-term unbuilt roads in city planning, as mentioned above.

As for the ideal provision of transport facilities in the future, in a period of depopulation, it is important to make skillful use of the roads that have taken time and money to construct. When the population was increasing, land use was rapidly promoted, and thus unavoidably the market took priority, but in this period of depopulation, it is important to adopt a viewpoint that emphasizes transportation infrastructure.

Rather than providing transportation facilities in response to land use based on free economic activities, it is essential that land use is guided in a favorable direction wherein the transportation facilities that have already been amassed are skillfully used.

How can transport guide land use? The answer lies in changes to transport systems. Cities achieved major growth due to changes to the main transport systems 
of walking, railroads, and automobiles. In other words, the advancement of transport systems has changed land use.

\subsection{Advanced Public Transport and City Planning}

What form will the next generation of public transport that will be used in the future take? The answer to that is not clear at present, but there are some transport systems that are attracting global attention in this regard.

Light rail transit (LRT) must be mentioned at the top of the list. Whereas railroads have been used to transport large numbers of passengers primarily between cities until now, attention is again being given to trams as a form of intra-city transport. The first LRT was introduced in Edmonton, Canada, in 1978, after which more cities began using it, so that 167 cities have newly introduced LRT as of the end of September 2016 (Hattori 2016). The difference from conventional trams is that LRT is a form of transport that has been coordinated for every aspect of travel, including low-floor carriages with excellent barrier-free accessibility, new carriages and tracks that produce little noise or vibration, a design that is integrated with tram stops, and electronic payment systems.

Figure 19.3 shows the LRT in Strasbourg that began operating in 1994. Rather than simply being another mode of transport, it is part of the attraction of the city, as it helps to increase the flow of pedestrians in the city and increase sales at commercial centers along the tracks.

Although the LRT is rapidly developing in locations around the world, the only example from Japan is that of the Toyama Light Rail in the city of Toyama. It began

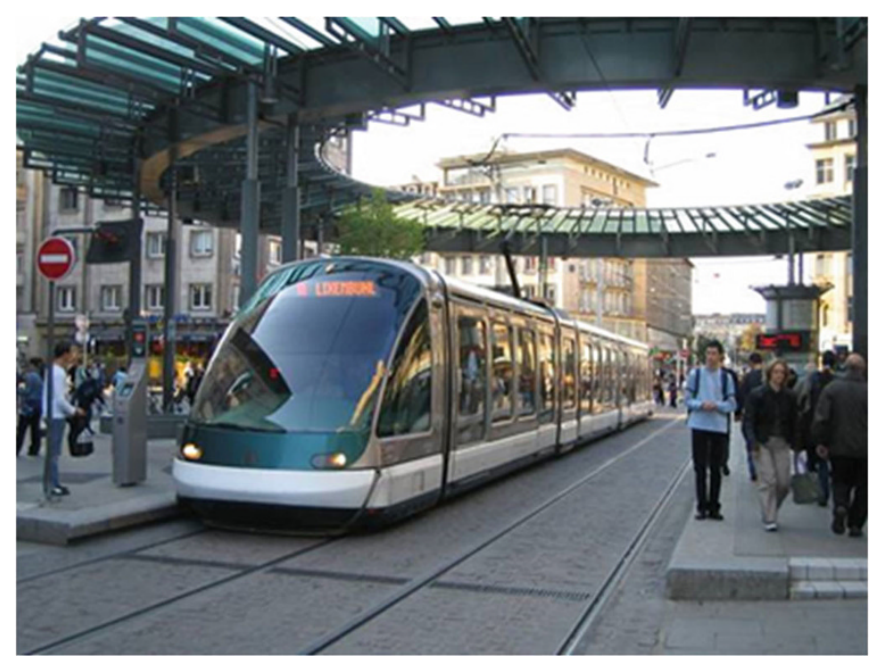

Fig. 19.3 Eurotram in Strasbourg (Germany) 
operating as an improved service for the existing Toyama Port Line in 2006, and it has made a major contribution to increased usage and the revitalization of the city center. Sustainable city planning in Toyama using the LRT is highly regarded in Japan and overseas, and it has won many awards. Although Japan's first LRT project is incredibly well regarded, no other city has introduced it so far.

Why has LRT not yet been more widely implemented, when the need for LRT is recognized and many cities have considered introducing it? The challenges for introducing LRT in Japan at present can be summarized in terms of financial issues and issues with building a consensus. A detailed description is not possible here, but the financial issues are triggered by Japan's public transportation policy which is based on a self-supporting accounting system. There are also many other issues, such as coordination with other transport businesses, consensus building with businesses and residents near railway tracks, and political activities related to the above.

\subsection{Utsunomiya LRT Introduction and Policy to Make the City More Compact}

Currently, Utsunomiya (population of 510,000), the prefectural capital of Tochigi, is receiving attention as the second candidate city for LRT introduction. Consideration on this matter goes back to 1993 and initially stemmed from an attempt to solve the chronic traffic congestion on the left bank of Kinugawa River on the east side of Utsunomiya Station by introducing a new transport system. By the twenty-first century, the regeneration of central urban areas became a major challenge, including revisions to what are referred to as the "Three Urban Development Laws." Consideration regarding the LRT extended approximately $3 \mathrm{~km}$ to the west side of Utsunomiya Station so that it would reach the city center. However, this resulted in conflict with bus operators that were providing services to the city center. Later, as the major challenges shifted to dealing with environmental issues and a depopulating society, the target for town planning underwent a major change from solution-based to target creation-based planning. In the Fifth Utsunomiya City Comprehensive Plan from 2008, a "network-based compact city" was positioned as the basic policy for urban space formation. In 2009, in the second Utsunomiya City Master Plan, LRT was positioned as the core of east-west main public transport system. In the Utsunomiya City transport strategy from the same year, a framework was defined for a comprehensive transport system that included the establishment of a plan for diverse transport systems such as automobiles and buses in coordination with LRT. To summarize the details so far, the story can be split into three phases based on the different primary planned targets (see Fig. 19.4).

While a legal plan has been established and a framework toward implementation has been demonstrated, each of the challenges stated above must be conquered in order to promote the actual introduction of LRT. 


\begin{tabular}{|c|c|c|c|c|c|c|}
\hline & 1993 & $\begin{array}{c}\text { Phase I } \\
1993 \sim 2002\end{array}$ & 2003 & $\begin{array}{c}\text { Phase II } \\
\text { 2003 2006 }\end{array}$ & 2007 & $\begin{array}{c}\text { Phase III } \\
2007 \sim\end{array}$ \\
\hline Actors & 䍐 & $\begin{array}{l}\text { City and Prefectural Governments } \\
\text { Developer Association, Economic } \\
\text { Organization, Transport } \\
\text { Companies }\end{array}$ & 홀 & $\begin{array}{l}\text { City and Prefectural } \\
\text { Governments, Citizens, } \\
\text { Transport Companies }\end{array}$ & 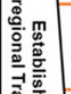 & $\begin{array}{l}\text { City and Prefectural } \\
\text { Governments, Citizens, } \\
\text { Business Operators, Transport } \\
\text { Companies }\end{array}$ \\
\hline $\begin{array}{l}\text { Place to } \\
\text { discuss }\end{array}$ & 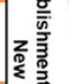 & $\begin{array}{l}\text { Study Group, Conference, } \\
\text { Exploratory Committee }\end{array}$ & 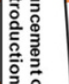 & $\begin{array}{l}\text { Conference, Exploratory } \\
\text { Committee, Briefing } \\
\text { Session for Citizens }\end{array}$ & 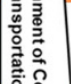 & $\begin{array}{l}\text { Conference, Exploratory } \\
\text { Committee, Briefing } \\
\text { Session for Citizens }\end{array}$ \\
\hline $\begin{array}{l}\text { Purpose of } \\
\text { LRT } \\
\text { introduction }\end{array}$ & 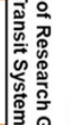 & $\begin{array}{l}\text { Countermeasure against the } \\
\text { issues of traffic jam on east to } \\
\text { Utsunomiya Station due to } \\
\text { automobile commuters passing } \\
\text { through Kinugawa River }\end{array}$ & 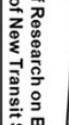 & $\begin{array}{l}\text { Transportation based } \\
\text { Planning for City } \\
\text { Revitalization by introducing } \\
\text { New transit system }\end{array}$ & 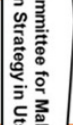 & $\begin{array}{l}\text { One measure as trunk } \\
\text { public transport for } \\
\text { realization of the network- } \\
\text { based compact city }\end{array}$ \\
\hline $\begin{array}{l}\text { Deliber- } \\
\text { ation }\end{array}$ & $\begin{array}{l}\text { 음 } \\
\stackrel{\circ}{y}\end{array}$ & $\begin{array}{l}\text { Appropriateness of LRT } \\
\text { introduction as a countermeasure } \\
\text { against the traffic jam } \\
\text { (considering alternative } \\
\text { measures such as construction of } \\
\text { bridge and road) }\end{array}$ & 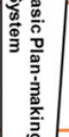 & Necessity of LRT introduction & 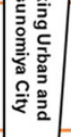 & $\begin{array}{l}\text { Whether the introduction of } \\
\text { LRT is most ideal for the } \\
\text { trunk public transport }\end{array}$ \\
\hline $\begin{array}{l}\text { Planning } \\
\text { Approac } \\
\text { ( target ) }\end{array}$ & & $\begin{array}{l}\text { Issue Resolution } \\
\text { Oriented } \\
\text { (Easing of traffic jam) }\end{array}$ & & $\begin{array}{l}\text { Solution-based } \\
\text { (regeneration of } \\
\text { central urban areas) }\end{array}$ & & $\begin{array}{l}\text { Target creation-based } \\
\text { (Vision for the future) }\end{array}$ \\
\hline
\end{tabular}

Fig. 19.4 Utsunomiya LRT route under consideration

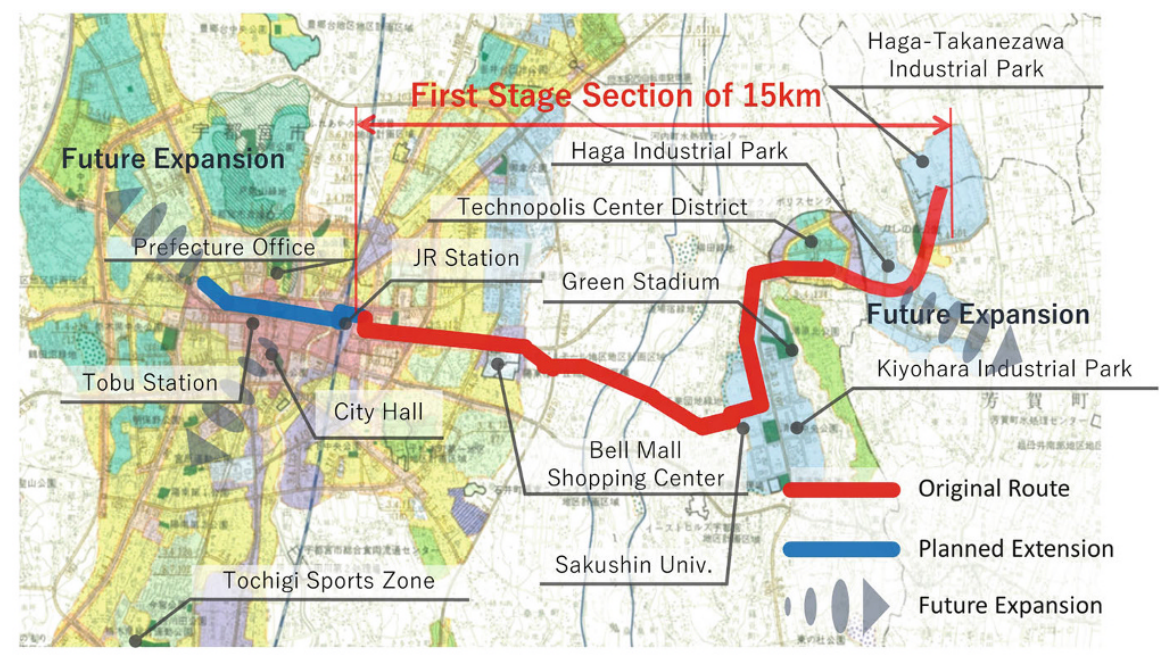

Fig. 19.5 LRT service route in Utsunomiya

The turning point in building a consensus began with PR activities in 2011 when an open consultation was held to explain LRT to citizens and in 2012 when the current mayor won a third election. The mayor, who understood that a common consensus had been reached regarding the introduction of LRT, began taking initiatives from 2013 to increase the project budget and to make changes to government staff. Because of the need to carefully build a consensus for the extension (approx. $3 \mathrm{~km}$ ) to the city center on the west side of the station, which had been 
heavily opposed, a policy was worked out for the initial supply of the first plan along the east side of the station (approx. $12 \mathrm{~km}$ ). Later, when Haga, a nearby town, requested an extension to the industrial park (approx. $3 \mathrm{~km}$ ), the Haga/Utsunomiya Main Public Transport Investigative Commission was established in November 2013, and full-scale studies began in connection to business profitability (see Fig. 19.5). After that, expectations increased regarding the introduction of LRT to the city center, including the issuance of a "Proposal regarding LRT business promotion and initial extension to the central town area" from the Utsunomiya City Development Promotion Organization in 2014, comprising mainly businesspeople from commerce and industry.

Meanwhile, regarding the financial issues, a large-scale study was made into transport volumes in 2014, which concluded that sufficient profitability could be anticipated, and the public-private Utsunomiya Light Rail Company Limited was established in November 2015. In May 2016, a city planning decision was made regarding the supply route, which was approved as an Advanced Railroad Transport Project by the Ministry of Land, Infrastructure, Transport and Tourism in September 2016 after undergoing a public hearing at the transportation commission. The current mayor won a fourth election in the November 2016 elections, and, while making efforts toward a PR campaign aimed at citizens, the aim is to start operation in March 2022 after a construction schedule of about 4 years.

Also, in order for Utsunomiya to become a network-based compact city, a location normalization plan was established in March 2017.

Of the ten urban function guidance areas, eight are designated as areas that include railroad stations and LRT stops (see Fig. 19.6). In particular, LRT is a major east-west public transport system that connects the city center, transit centers, and the suburbs, which, when completed, will be the first case in Japan of an LRT with entirely new lines.

\subsection{Automated Driving and Compact Cities}

In terms of advanced transport systems that affect land use, attention must also be given to automated driving. This is a visionary mode of transport which is able to move to the destination without a driver, and it is an extremely effective form of technology for both mitigating congestion and ensuring safe transport. However, it may also be the case that a second wave of motorization brought about by automated driving may also promote further suburbanization of urban areas. For local governments that are promoting policies to make cities more compact, automated driving technology may be a favorable or opposing wind, depending on how it is used. According to the 2014 definition from the Society of Automobile Engineers (SAE) in the United States, there are the following categories of automated driving (see Table 19.2) (SAE 2014). 


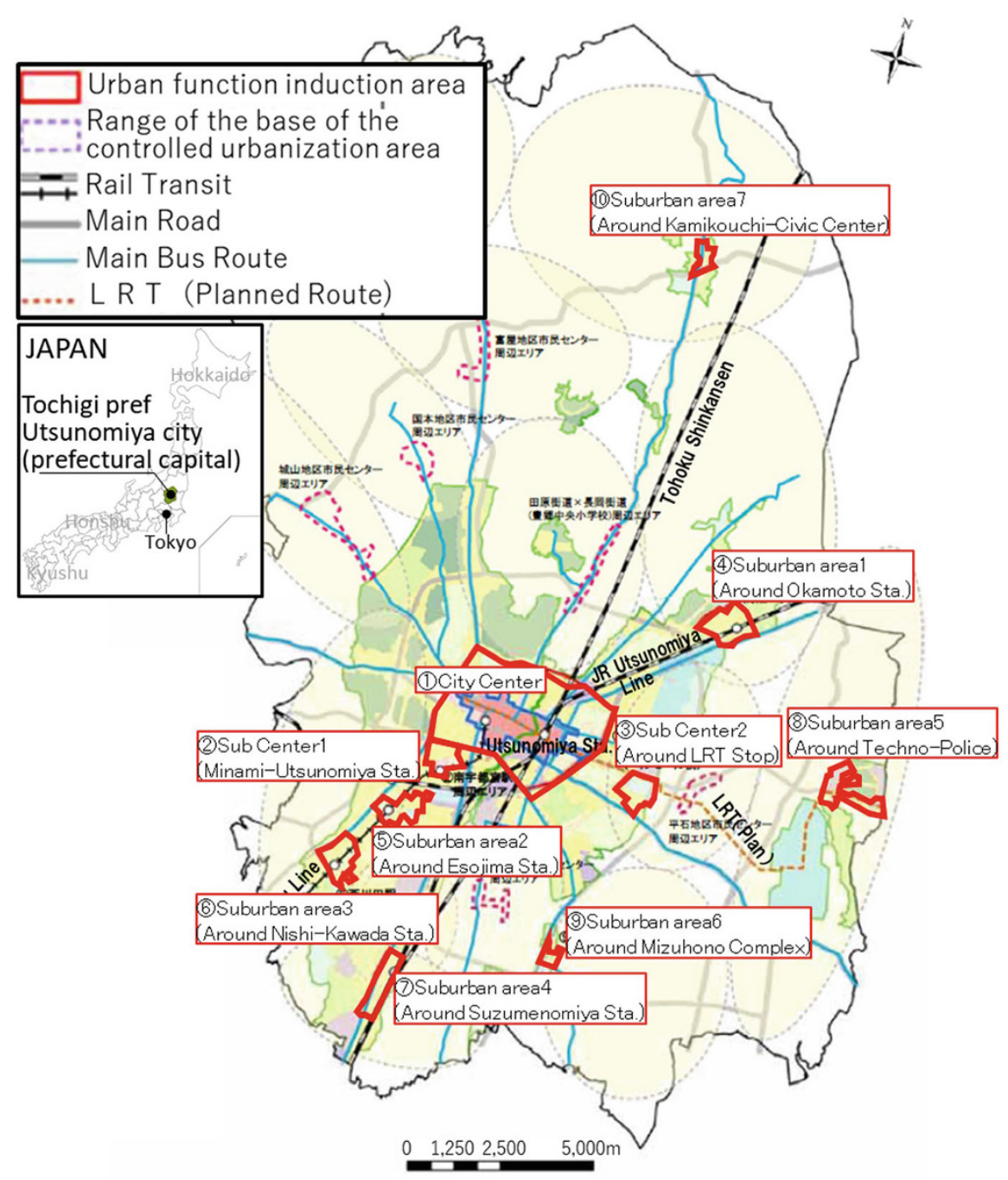

Fig. 19.6 Utsunomiya City location normalization plan

Although the person driving is the operator until Level 2, the system is driving from Level 3 onward. Furthermore, from Level 4, a driver is not required, and the vehicle can be operated even after drinking alcohol or by older people who do not have licenses.

From the viewpoint of city planning, attention should be given to the spread of Level 4 automated driving technology. This should preferably be introduced in limited strategic areas in order to increase social benefits. In city suburbs and rural towns, in particular, public transport is in decline due to depopulation and an aging 
Table 19.2 Definitions of automated driving levels (SAE J3016)

\begin{tabular}{l|l}
\hline $\begin{array}{l}\text { SAE level (SAE } \\
\text { name) }\end{array}$ & SAE narrative definition \\
\hline $\begin{array}{l}\text { Level 0 } \\
\text { (no automation) }\end{array}$ & The full-time performance by the human driver \\
\hline $\begin{array}{l}\text { Level 1 } \\
\text { (driver assistance) }\end{array}$ & $\begin{array}{l}\text { The driving made-specific execution by a driver assistance system of either } \\
\text { steering or acceleration/deceleration }\end{array}$ \\
\hline $\begin{array}{l}\text { Level } 2 \\
\text { (partial } \\
\text { automation) }\end{array}$ & $\begin{array}{l}\text { The driving made-specific execution of one or more driver assistance } \\
\text { systems of both steering and acceleration/deceleration. }\end{array}$ \\
\hline $\begin{array}{l}\text { Level } 3 \\
\text { (conditional } \\
\text { automation) }\end{array}$ & $\begin{array}{l}\text { The driving made-specific performance by an automated driving system of } \\
\text { all aspects of the dynamic driving task }\end{array}$ \\
\hline $\begin{array}{l}\text { Level } 4 \\
\text { (high automation) }\end{array}$ & $\begin{array}{l}\text { The driving made-specific performance by an automated driving system of } \\
\text { all aspects of the dynamic driving task }\end{array}$ \\
\hline $\begin{array}{l}\text { Level 5 } \\
\text { (full automation) }\end{array}$ & $\begin{array}{l}\text { The full-time performance by an automated driving system of all aspects of } \\
\text { the dynamic driving task }\end{array}$ \\
\hline
\end{tabular}

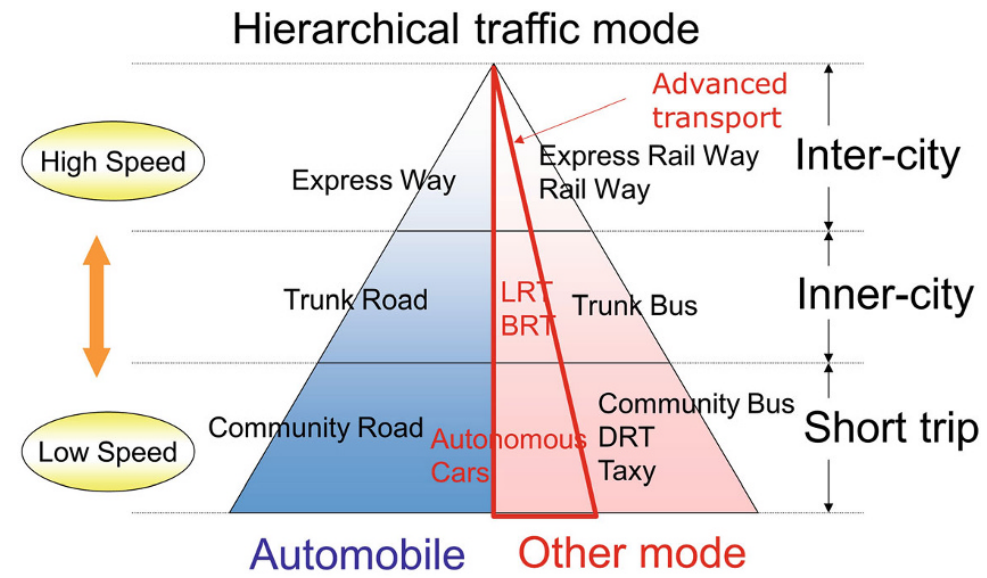

Fig. 19.7 Urban traffic strategy for next step

society, and securing mobility is a major challenge. A rapidly aging society could be supported by introducing automated driving technology in regions where public transport is not convenient.

Figure 19.7 shows the preferable transport systems for the near future. Trunk line systems of network are provided using LRT and other advanced public transport, while areas spreading out from transportation hubs are covered by branch line public transport systems adopting automated driving technology.

The key to forming network-based compact cities is the construction of public transport systems with different roles played by main lines and branch lines. Figure 19.8 shows an illustration of a compact city and transport spaces. Transportation hubs are connected by public transport systems on the main line, which 


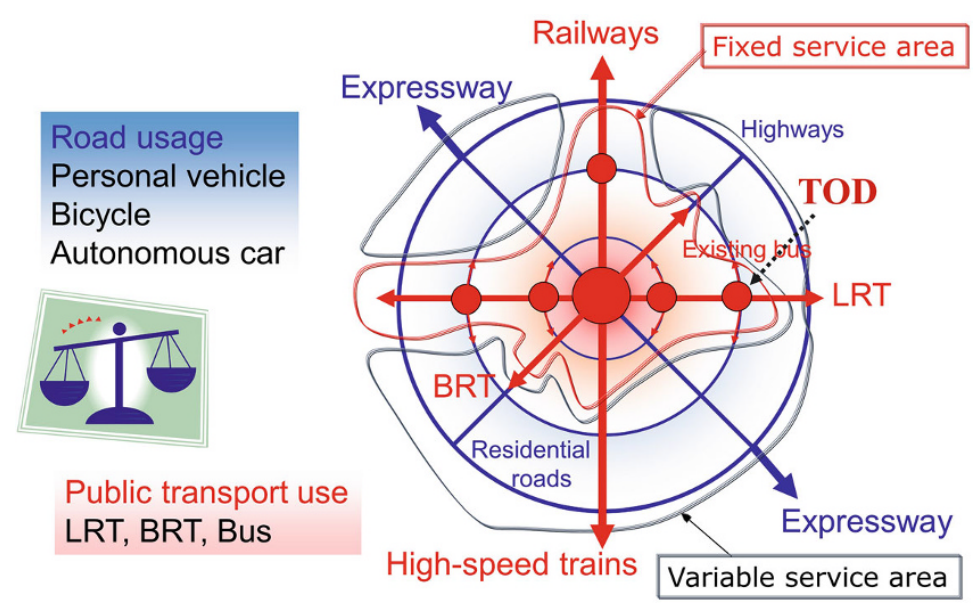

Fig. 19.8 Transport systems that encourage urban consolidation

ensures regularity and speed. It is also necessary to make efforts to increase the attractiveness of city spaces by means of vehicle design and so on that are integrated with city development. Meanwhile, branch lines will utilize transport systems for flexible route selection, including walking, bicycles, personal mobility, and automated operation vehicles. Areas around stations and tram stops will prioritize walking and cycling with the aim of creating spaces that make walking enjoyable, and residential roads will become safe transport areas with upper speed limits of $30 \mathrm{~km} / \mathrm{h}$. Urban areas are shrinking due to depopulation in areas where services are provided by branch line systems, and so flexible transport systems would be a suitable response to this.

\subsection{Conclusion}

Until now, transport systems have been provided as a whole while maintaining a certain balance between private transport, such as automobiles, and public transport, such as railroads and buses. However, as public transport has fallen into decline with the rise of automobiles, that balance has largely been lost, and cities have become overly dependent on private transport. In order to form compact urban areas in line with a depopulating society, that balance must be regained.

Even if current automobiles are converted to automatic operation (Level 5) in the future, there will be a period in the process of introduction in which manual operation is mixed with automatic operation. During that period, it is important that the characteristics and roles of each transport system are reorganized and that they are skillfully incorporated into cities. In particular, the formation of transfer 
points between main line and branch line in the transport systems is a key to the formation of compact cities.

\section{References}

Gakenheimer R (1993) Land/use transportation planning: new possibilities for developing and developed countries. Transp. Quart. 47(2):311-322

Hattori S (2016) Current situation of LRT in 2016. In Proceedings of national conference toward the Eco-Friendly traffic in Fukui, pp. 57-58

SAE $(2014,2014)$ Taxonomy and definitions for terms related to on-road motor vehicle automated driving systems J3016_201401. SAE International

Open Access This chapter is licensed under the terms of the Creative Commons Attribution 4.0 International License (http://creativecommons.org/licenses/by/4.0/), which permits use, sharing, adaptation, distribution and reproduction in any medium or format, as long as you give appropriate credit to the original author(s) and the source, provide a link to the Creative Commons licence and indicate if changes were made.

The images or other third party material in this chapter are included in the chapter's Creative Commons licence, unless indicated otherwise in a credit line to the material. If material is not included in the chapter's Creative Commons licence and your intended use is not permitted by statutory regulation or exceeds the permitted use, you will need to obtain permission directly from the copyright holder. 